\title{
Embedding Sustainable Consumption into Higher Education in Vietnam
}

\author{
Son Tung Ha Manh Dung Tran \\ National Economics University, Vietnam \\ Dinh Trung Nguyen Thi Minh Ngoc Hoang \\ National Economics University, Vietnam
}

\begin{abstract}
Changing in the way that human produces and consumes are indispensable to achieve sustainable consumption. All of the countries in developed economies, economies in transition and developing economies should promote sustainable consumption. This will require larger changes in society. Higher education plays a vital role in promoting understanding, awareness of professors, staff members and students of sustainable consumption. Through higher education, these people would be positively change their mind about this issue. National Economics University (NEU) is one of the leading university in economics in Vietnam as a case study. Students graduated from the university will be future experts, leaders and businessmen. After graduation, as academic citizens with acquainted knowledge and skills, they will influence the economic and social changes though their business and private purchasing habits and decisions. Using data from the University, this paper will reveal the current landscape of sustainable consumption at National Economics University through the years. In order to embed this issues into education, the university should incorporate sustainable consumption into the curriculum, create and implement a sustainability plan and adjust teaching method to encourage students asking questions, analyzing, thinking critically and making decisions toward sustainable consumption.
\end{abstract}

Keywords: Embedding sustainable consumption, higher education

DOI: $10.7176 / \mathrm{EJBM} / 11-18-12$

Publication date:June $30^{\text {th }} 2019$

\section{Introduction}

Current consumption patterns have caused huge pressure on the planet. With global population expected to grow from 7.6 billion in 2017 to 9.8 billion by 2050, and more people joining the middle class, the environment will suffer irreversible damage if our unsustainable lifestyle continues. On one hand, individual welfare improves with increasing prosperity; on the other hand, higher demand for resources creates a variety of environmental and social problems (United Nations, Department of Economic and Social Affairs, 2017). This is noticed from the research of Penna (1999), the extraordinary increase in the human population in the twentieth century, of the intensified urbanization and of the industrialization in most countries is one of the reason. Besides, there are some other reasons such as climate change (Wallen et al., 2004), the erosion of biodiversity (Liu et al., 2003) and also the depletion of mineral and energy resources (Carlsson et al., 2005). Sustainable Consumption Institute (2003) stated that changing consumer behavior is particularly problematic, especially in societies where the freedom of consumer choice is highly valued.

As Marglin (2013) notes, a new economy requires a new economics such as the reorientation of both the demand and supply sides of growth will require a fundamentally different role of the market recognizing the limits of the invisible hand resulting in different economic, social and environmental problems. A new economy will need a broader view of economics, which goes beyond the calculating, self-interested, individual to take account of community, compassion and cosmos. A new economics should be based on a basic insight of ecological economics, namely, the fundamental interdependence of humans and the rest of nature. Kristina and Matea (2014) pointed out consumer behaviour directly influences the methods of production and the level of environmental awareness in the business community, and therefore unsustainable consumption patterns are no longer acceptable. Thus, higher education plays a vital role in enhancing understanding and awareness sustainable consumption, emphasize on importance of promoting understanding, awareness of students of sustainable consumption.

The purpose of this paper is to provide a brief literature review about sustainable consumption and promoting understanding, awareness of sustainable consumption of students, professors and other staff members, at National Economics University in Vietnam.

\section{Literature review}

2.1 Sustainable consumption

Since 1972, problems related to consumption have been recognized. Through the time, there is an increasing of studies of the general interest in sustainable consumption (Straughan and Roberts, 1999; Fraj and Martinez, 2007). This shows a positive signal for society. However, there is little consensus in defining sustainable consumption, 
and it is widely recognized to be a contested concept (Seyfang, 2004). Marchand and Findeli (2003) have argued that sustainable consumption is a goal with uncertain boundaries and that it has no clear definition, nor are its implications well understood. In that light, the UK Sustainable Development Commission (2003) has recognized the difficulty of defining sustainable consumption.

Meadows et al. (1972) suggested the model of consequences of the growing world's population, economic growth and increase in pollution, production and consumption, and point out the continuous resource depletion and environmental deterioration. Through the time, sustainable consumption is still a young concept. There have some definitions of sustainable consumption come from programs, researchers from different looks. In 1992, at the United Nations Conference on Environment and Development (UNCED, 1992) the concept of sustainable consumption was proposed in chapter 4 of the Agenda 21: Although consumption patterns are very high in certain parts of the world, the basic consumer needs of a large section of humanity are not being met. This results in excessive demands and unsustainable lifestyles among the richer segments, which place immense stress on the environment. The poorer segments, meanwhile, are unable to meet food, health care, shelter and educational needs. Changing consumption patterns will require a multipronged strategy focusing on demand, meeting the basic needs of the poor, and reducing wastage and the use of finite resources in the production process. In addition, the definition proposed by the 1994 Oslo Symposium on Sustainable Consumption defines it as the use of goods and services that respond to basic needs and bring a better quality of life while minimizing the use of natural resources and toxic materials as well as emissions of waste and pollutants over the life cycle of the service or product so as not to jeopardize the needs of future generations (Norwegian Ministry of the Environment, 1994). The United Nations Environment Programme (1992) defines sustainable consumption as the use of services and related products that respond to basic needs and bring a better quality of life while minimizing the use of natural resources and toxic materials as well as the emissions of waste and pollutants over the life cycle so as not to jeopardize the needs of future generations. Dahl (1998) pointed out that sustainable consumption refers to the need to stay within the global sustainability of resources. Ribeiro, Veiga \& Higuchi (2016) added the search for ecologically-correct products and services, the preference for corporations and organizations actively engaged in environment conservation, the saving of resources such as water and energy, the using of materials and equipment up to the end of its life service, the reusing, whenever possible, the right destination of residuals to recycling and the propensity to a lifestyle with a smaller negative environmental impact.

Researches from Peattie (2001), Fraj \& Martinez (2007) noticed that sustainable consumption must be widely understood, including activities and everyday consumer practices like the reduction of water, materials and energy consumption, the active participation in recycling, the support for environment-friendly companies and the economy of resources. This is in line with findings of Engel, Blackwell \& Miniard (2000) that those daily activities directly involved in obtaining, consuming and disposing of products and services, including the decision processes that precede and follow these actions.

The European Commission (2012b) recognized that sustainable consumption is seen by some as a reversal of progress towards greater quality of life in that it would involve a sacrifice of our current, tangible needs and desires in the name of an uncertain future. Sustainable consumption can no longer mean voluntary refraining from some of the consumption options available (which were part of an unsustainable development and waiving them was of limited effectiveness due to rebound effects), but the ability to lead to a dignified life, maintaining or enhancing quality of life despite shrinking resource availability (Lorek \& Spangenberg, 2014). So, the ultimate purpose of sustainable consumption is to gives consumers the opportunity to consume products, use services that meet their needs effectively, minimizing negative environmental, social, and economic consequences. With which, it helps to improve and upgrade the quality of life of both current and future generations of consumers.

\subsection{Sustainable consumption and higher education}

Ropke (2009) concluded that the practice perspective emphasizes the immense challenge involved in promoting sustainable consumption and the practice perspective suggests that moralizing or trying to persuade individuals that curbing consumption would contribute to both environmental improvements and increased well-being - has little chance of success. Consumers have a key role through altering their materialistic consumption patterns and lifestyles, motivated by a growing awareness of the impact of their choices on the environment (Kristina \& Matea, 2016). The way people live, the actions that people take can directly or indirectly impact on the environment. In that light, the diversity and scale of ecological issues linked with household consumption require everyone to be educated in more responsible consumption (UNESCO, 2005). Higher educations in this case are very important to provide, enhance knowledge of sustainable consumption for students who are consumers and will be future experts, leaders and businessmen. Students, after graduation, as academic citizens, with the implantation of acquainted knowledge and skills, will influence the economic and social changes though their business and private purchasing habits and decisions (Kristina \& Matea, 2016). People with higher levels of education are more likely to hold proenvironmental attitudes and to have a greater sense of efficacy that facilitates their participation in movements (Liere \& Dunlap, 1980). 
Higher education institutions as universities can make a positive impact on students, professors and other staff members, making them mindful about the importance of reducing water and energy consumption, but also teaching them to diminish waste production, to recycle and changing their habits into more sustainable ones (Katiliūtè et al., 2014). Education went alongside the development of more comprehensive learning outcomes that had been conceptualized as key competencies for sustainable consumption (Fischer \& Barth, 2014). By transferring knowledge through teaching process and results of scientific researches or even through implementing sustainable consumption based strategic planning, universities could educate students on sustainable consumption. Sustainable consumption can embed into higher education by various ways such as embedding topics of the environment and its sustainability, ethics in business into curriculum, applying appropriate teaching methods to encourage students to ask questions, analyze, think critically and make decisions toward sustainable consumption and create and implement a sustainability plan.

The focus on internal processes to transform sustainable consumption into actions of higher education is also vital. Sustainable consumption based strategic planning might relate to utilizing its resources, such as energy, water and other resources; stimulating a sustainable waste management and recycling practice; reducing the institutional ecological footprint; and enhancing its market visibility (Rauen et al., 2015; Adomßent et al., 2014). Thus, it is important that universities should reorganize the entire knowledge utilization process from a liner, sequential and instrumental process into a deliberative process of capacity building through knowledge co-production (i.e. joint involvement in all stages of research, policy development and use) (Heiskanen et al., 2013).

Higher education is one of the places with the most consumption of paper. The paper used for teachers' learning and teaching purposes is extremely reasonable. However, sometimes it causes waste if we don't make the most of it. Thus, paper usage is significant. According to research by Oke (2015), the depletion of natural resources and the production of its accompanying waste have been linked to human behavior. Human can reduce the amount of waste produced, also implement recycling programs to reduce their environmental impact and stimulate replication of sustainable activities outside the organization. Also, water management is important. According to McHugh's study (2011), integrated water resource management (IWRM) is a leading model of sustainable water resource management, allowing universities to address numerical problems related to water quality. Universities have a number of characteristics that enable them to act as models and effective testing facilities for sustainable water resource management. Adomßent (2014) pointed out higher education institutions that can implement energy efficiency to reduce energy consumption, increase the rate of renewable energy and reduce the impact on the environment. Managing sustainable energy sources not only helps higher educations to be more economical, but it can also re-create new sources of energy to re-consume higher educations.

\section{Research Findings}

Founded in 1956, National Economics University (NEU) is one of the leading universities in Economics, Public Management and Business Administration in Vietnam. NEU places a high priority on the quality of teaching and on preparing students for employment in an increasingly competitive, international environment. NEU currently offers training to nearly 45,000 students annually at Bachelor, Master and Ph.D levels.

The vision and mission statement of NEU are:

- Mission

Being the national key university, the leading university in training economics, management and business administration in Vietnam, NEU's mission is to provide society with qualified education, research, consultancy and technology-transfer-services attaining regional and international level, and to contribute to national industrialization - urbanization in the context of global economic integration.

- Vision

NEU strives to become a prestigious multi-disciplinary and research oriented university reaching regional and international quality in the field of economics, management, business administration and other key areas. It endeavors to be ranked in the world's top 1000 universities in the next decade.

Though NEU mission does not directly mention about sustainable consumption, one of the NEU mission is to provide society with qualified education, research attaining regional and international level, and to contribute to national industrialization - urbanization in the context of global economic integration. This also means that the university is willing contributing to make a better life, including developing ecologically responsible lifestyles.

To access how NEU embed sustainable consumption into the University, we would look at numbers of subjects and researches related to sustainable consumption at NEU. On one hand, the university must transfer the ideas of sustainable consumption through subjects in curriculum to help students understand and change the behavior toward sustainable consumption. On the other hand, researches of lecturers and students related to sustainable consumption is also important. This will help society have a deep look into the issues. Numbers of subjects in curriculum and researches related to sustainable consumption at NEU are shown in the table 1. 
Table 1. Numbers of subjects in curriculum and researches related to sustainable consumption at NEU

\begin{tabular}{lccc}
\hline & $\mathbf{2 0 1 6}$ & $\mathbf{2 0 1 7}$ & $\mathbf{2 0 1 8}$ \\
\hline Number of subjects in curriculum related to sustainable consumption & $2 / 1192$ & $2 / 1192$ & $2 / 1192$ \\
Number of students' researches related to sustainable consumption & $4 / 41$ & $4 / 80$ & $7 / 156$ \\
Number of lecturer's researches related to sustainable consumption & $3 / 75$ & $4 / 66$ & $4 / 69$ \\
\hline
\end{tabular}

The result shows that among 55 majors and 1192 subjects in curriculum of NEU, there is no subjects exactly on sustainable consumption. This is not a good sign for embedding sustainable consumption into higher education, especially NEU is one of the biggest university in Vietnam in economics. Of 1192 subjects, there are a several subjects related to sustainable consumption such as sustainable development which is exclusively for development economics major or customer behavior which is exclusively for marketing major. At the university, there are some other subjects related to corporate social responsibility such as Business ethics, Business Intelligence, Management and Ecology and Sustainable Development or Business Strategy. However, those subjects are not directly mention about sustainable consumption. This is not in line with the biennial survey of 91 U.S. business schools by the World Resources Institute and the Aspen Institute, published in October 2005 that $54 \%$ of business schools require a course in environmental sustainability or corporate social responsibility. This is also strengthened by the research of Jyotsna \& Ananda (2012), while there has been significant growth among business schools with regard to teaching of environmental issues, nearly half of business schools have no such programs.

In terms of students' researching, it is appearing to be limited availability of relevant topic related to sustainable consumption. Only 4 of 44 researches (9\%) in 2016, 4 of 80 (5\%) 2017 and 7 of 156 (4.5\%) in 2018 researches are related to sustainable consumption. Though the number of researches increased sharply in 2018 , the ratio of researches related to the topic is limited. This could very well imply about low level of consideration of the topic from students' side.

In terms of lecturers' researches, only 3 of 75 researches (4\%) in 2016, 4 of $66(6 \%) 2017$ and 4 of 69 (6\%) in 2018 researches are related to sustainable consumption. The result shows that the level of consideration about the topic is substantially lower than it should be. With such result, it seems not enough to embed the importance of sustainable consumption for current and future generations. Therefore, it is hard to influence the awareness of students.

To some extents, sustainable consumption also can be reflected through internal processes of the university.

Table 2. Numbers of staff, teachers and students at NEU

\begin{tabular}{lccc}
\hline & $\mathbf{2 0 1 6}$ & $\mathbf{2 0 1 7}$ & $\mathbf{2 0 1 8}$ \\
\hline Number of staff & 527 & 534 & 546 \\
Number of teachers & 797 & 807 & 811 \\
Number of students & 4800 & 4800 & 5500 \\
Number of rooms & 114 & 261 & 264 \\
\hline
\end{tabular}

The data shows that number of staff and teachers at the University are almost unchanged between 2016, 2017 and 2018. However, in 2018, number of students increased to 5500 students while in 2017, it was only 4800 students. Besides, number of rooms increase as well. With such numbers, sustainable consumption at NEU would be accessed through paper usage, electricity usage, and water usage as following.

- Paper usage:

Table 3. Paper usage per year at NEU

\begin{tabular}{lccc}
\hline & $\mathbf{2 0 1 6}$ & $\mathbf{2 0 1 7}$ & $\mathbf{2 0 1 8}$ \\
\hline Number of papers (kg) & 1723 & 1743 & 1692 \\
Price/ kg (USD) & 12.39 & 13.04 & 15.65 \\
Total (USD) & $21,347,000$ & $22,728,000$ & $26,495,000$ \\
\hline
\end{tabular}

The result shows that there is a remarkable difference between 2017 and 2018 in total of money spent in paper usage. The reason is number of students and price per $\mathrm{kg}$ increase. So, this could be a good sign in sustainable consumption in terms of paper usage because the use of paper is preferred by students because of longer materials and sustainable reading, because supporting paper easily annotates and highlights text, allowing more movement in posture and position read and does not depend on electricity, battery or internet connection (Taipale, 2014).

- Electricity usage:

At NEU, electricity is used in the active buildings as well as equipment's for various purposes. The number of electricity usage is shown in the figure 1 as following: 


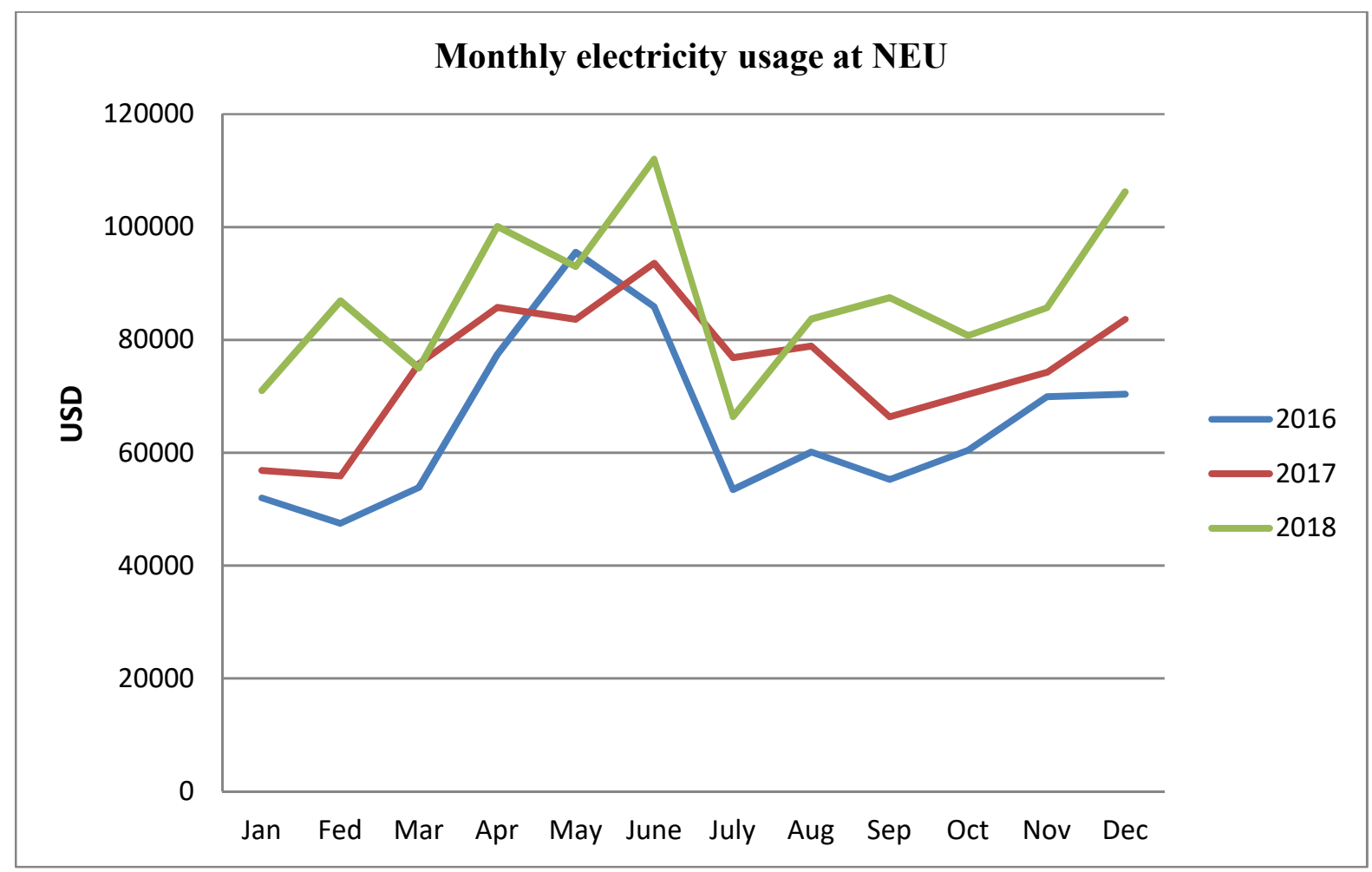

Figure 1. Monthly electricity usage at NEU

The result shows that there is a difference between months in electricity usage at NEU, especially high in April, May and December. This could be explained that this is also some of the hottest and coldest times of the year. Thus, all of classrooms are used air conditioning and heating. Total money spending on electricity usage also increased from 2016 to 2018 because of price per unit of electricity increased sharply, number of students and number of rooms increase through the years as well.

- Water usage:

12000

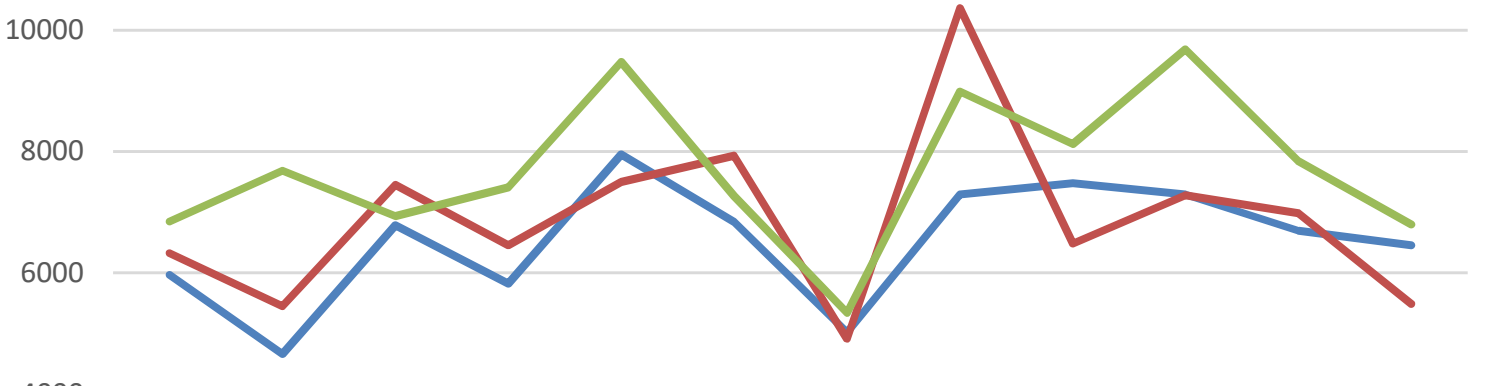

4000

2000

Jan Feb Mar Apr May June July Aug Sep Oct Nov Dec

Figure 2. Monthly water usage at NEU

The date shows that annually, April, May and August are the largest month and February and July are the lowest month in water consumption in year. This could be explained by period of studying and the weather as well. 
April, May and August are hottest period of the year and these months are also intensive period of studying.

It can be seen that the consumption of electricity, water, and paper at NEU has increased steadily over the years. However, with increasing of numbers of students and number of rooms, the amount of consumed electricity, water, and paper at NEU did not increase significantly. This proves that employees, lecturers and students of the school are also more conscious of sustainable consumption.

\section{Recommendations}

From the literature review and finding results, it is crucial that the University should pay attention on embedding sustainable consumption into higher education. The following are some suggestions:

First, aspects of sustainable consumption should be incorporated in the curriculum. The curriculum must be followed documents toward sustainable consumption such as:

- Approval of sustainable development strategy of Vietnam in Decision 432/QD-TTg dated 12 April 2012.

- Approving national strategy on green growth of Vietnam in Decision 1393/QD-TTg dated September 25, 2012.

- Approving the National Action Program on sustainable production and consumption up to 2020, with a vision toward 2030 in Decision 76/QD-TTg dated 11 Jan 2016 of the Prime Minister;

- The National Action Plan to implement the 2030 Agenda for SDGs (SDG NAP) was promulgated as per Decision 633/QD-TTg dated 10 May 2017 of the Prime Minister.

All stated documents indicate that the University should care about the efficacy and impact of this aspect of education in creating knowledge and awareness of sustainable consumption. In this light, education should be related to sustainable development, sustainable consumption and also sustainable practices. Education for sustainable practices is related with encouraging employees and students to be proactive in their local communities, to act as responsible individuals and consumers, while education through sustainable practices is related with the implementation of sustainability practices in the management process of the universities (e.g. through creation and implementation of sustainability strategy by involving different stakeholders, through sustainability reports, etc.) (Kristina \& Matea, 2016). In other words, it is fundamental that courses related to sustainable development such as sustainable consumption and production, corporate social responsibility, sustainable tourism, sustainable marketing, social economy, business ethics etc. should be offered to students in various majors.

Second, aside curriculum, sustainable consumption should be created and implemented as a sustainability plan relating to proper waste disposal such as double-sided printing, reducing the amount of papers used, distributing mugs made with recycled material; rationalize energy use such as rationalize water use, electricity use, fuel consumed; criterion in services and buildings such as reduce quantity of solid waste; enhance awareness among the internal community such as awareness of professors and other staff members. These issues should be embedded in culture of the university. The use of resources to fulfil functions of teaching, research, outreach and partnership, and stewardship is very crucial to help society make the transition to sustainable lifestyles. This also in line with the findings of Soini and Birkeland (2014) that culture must be changed appropriately because achieving sustainability goals essentially depends on human accounts, actions, and behaviors which are, in turn, culturally embedded.

Third, though courses related to sustainable consumption integrated in curriculum are important, it is more crucial that professors, teachers should adjust their teaching methods in which students are stimulated to ask questions, analyze, think critically and make decisions toward to sustainable consumption. Further, professors, teachers and researchers should care more about sustainable consumption or sustainable practices in their research topics. By which, they can drive their students in choosing research topics related to sustainable consumption or sustainable practices.

\section{Conclusion}

Process with the participation of education helps ensure sustainable consumer actions at multiple levels, ages and different countries, thereby providing a more aware generation of sustainable consumption with a more sustainable future (Lea, Stephenson \& Troy, 2003). There are various ways to embed sustainable consumption into higher education. The findings and discussion from the paper implies that professors, teachers and researchers at NEU are not really focus on sustainable consumption or sustainable practices in their researches. Also, the university curriculum is not covered enough courses related to sustainable consumption or sustainable practices. This paper suggested for some changes including changing in curriculum, teaching method and implementing a sustainability plan at the University so that students can change their awareness and behavior in the future.

\section{References}

Adomßent, M., Fischer, D., Godemann, J., Herzig, C., Otte, I., Rieckmann, M. and Timm, J. (2014), Emerging areas in research on higher education for sustainable development management education, sustainable consumption and perspectives from central and Eastern Europe, Journal of Cleaner Production, 62, 1-7.

Carlsson, A., Engstrom, R. and Kok, R. (2005), Indirect and direct energy requirements of city households in 
Sweden: options for reduction, lessons from modelling, Journal of Industrial Ecology, 9(1/2), 221-235

Dahl, L.A. (1998), Sustainable consumption and true prosperity, retrieved on Nov 10 ${ }^{\text {th }}, 2018$ from https://bahailibrary.com/dahl_sustainable_consumption_prosperity

Engel, J. F., Blackwell, R. D., \& Miniard, P. W. (2000), Comportamento do consumidor. (8a. ed.) Rio de Janeiro: LTC.

European Commission (2012b), Policies to encourage sustainable consumption, retrieved on Nov 15th, 2018 from http://ec.europa.eu/environment/eussd/pdf/report_22082012.pdff.

Fischer, D., \& Barth, M. (2014), Key competencies for and beyond sustainable consumption: An educational contribution to the debate. GAiA, 23(S1), 193-200.

Fraj, E., \& Martinez, E. (2006), Influence of personality in ecological consumer behavior, Journal of Consumer Behavior, 5(3), 167-181.

Heiskanen, E., Mont, O., Power, K. (2014): A Map Is Not a Territory - Making Research More Helpful for Sustainable Consumption Policy, Springer Science + Business Media, New York.

Jyotsna M. \& Ananda M. (2012), Attitudes Toward Sustainable Consumption: The Impact of Business Education and Personal Values, 10 (1), 34-41.

Kristina A. R \& Matea T. (2016), Promoting sustainable consumption through higher education, 13th International Scientific Conference on Economic and Social Development, Barcelona.

Katiliūtè, E., Daunorienè, A. and Katkute, J. (2014), Communicating the sustainability issues in higher education institutions worldwide webs, Procedia - Social and Behavioral Sciences, Vol. 156, 106-110.

Lea, S. J., Stephenson, D., \& Troy, J. (2003), Higher education students' attitudes to student-centred learning: Beyond "educational bulimia"? Studies in Higher Education, 28, 321-334.

Liere, V.K.D. and Dunlap, R.E. (1980), The Social Bases of environmental concern: A review of Hypotheses, Explanations and Empirical Evidence, Public Opinion Quarterly, 44, 181-97.

Lorek, S. \& Spangeberg, J.H. (2014), Sustainable consumption within a sustainable economy beyond green growth and green economies, Journal of Cleaner Production, 63, 33-44.

Liu, J., Daily, G.C., Ehrlich, P.R. and Luck, G.W. (2003), Effects of household dynamics on resource consumption and biodiversity, Nature, 421(22), 530-533.

Marglin A.S. (2013), Premises for a new economy \& act, Journal of Development, 56(2), 149-154.

Marchand, A. and Findeli, A. (2003), Understanding users of sustainable consumption: triggers for innovation, retrieved on Nov 23th, 2018 from www.cfsd.org.uk/events/tspd8/abstracts/annemarchand.doc

McHugh, A. (2011), An Assessment of Sustainable Water Management at University Campuses. Duke University,

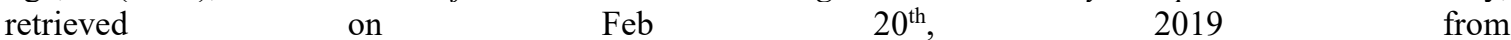
https://dukespace.lib.duke.edu/dspace/.../5023/McHugh_duke_0066D_11200.pdf

Meadows, D. H., Meadows D. L., Randers J. and Behrens W. W (1972), The limits to growth, New York: Universe Books.

Norwegian Ministry of the Environment (1994), Report from the Oslo Ministerial Roundtable Conference on Sustainable Production and Consumption, Oslo Symposium.

Oke, A. (2015), Workplace Waste Recycling Behaviour: A Meta-Analytical Review, 7175-7194, retrieved on Jan $20^{\text {th }}, 2019$ from https://www.mdpi.com/journal/sustainability

Rauen, T.R.S., Lezana, A.G.R. and Silva, V. (2015), Environmental management: an overview in higher education institutions, Procedia Manufacturing, 3, 3682-3688.

Ribeiro, J., Veiga, R., \& Higuchi, A. (2016), Personality Traits and Sustainable Consumption, Journal of Marketing - BJM, 15(3), 23-31.

Ropke, I. (2009), Theories of practice - new inspiration for ecological economic studies, ecological economic studies on consumption, Vol. 68 No. 10, 2400-2497, retrieved on Jan $5^{\text {th }}$ from www.sciencedirect.com/science/article/pii/S0921800909002249.

Peattie, K. (2001). Golden Goose Or Wild Goose? The Hunt For The Green Consumer, Business Strategy and the Environment, 10, 187-199.

Penna, C. G. (1999), O estado do planeta: Sociedade de consumo e degradação ambiental, Rio de Janeiro: Record.

Seyfang, G. (2006), Ecological citizenship and sustainable consumption: examining local organic networks, Rural Studies, 22(4), 383-395.

Soini K., and Birkeland I. (2014), Exploring the Scientific Discourse on Cultural Sustainability, Geoforum, 51, 213-223.

Straughan, R. D., and Roberts, J. A. (1999), Environmental segmentation alternatives: A look at green consumer behavior in the new millennium, Journal of Consumer Marketing, 6(6), 558-575.

Taipale, S (2014), The affordances of reading/writing on paper and digitally in Finland, Telematics and Informatics. 31(4), 532-542.

UK Sustainable Development Commission (2003), Policies for sustainable development, retrieved on Nov 15 th, 2018 
www.sd-commission.org.uk/data/files/publications/Policies_sust_consumption.pdf

UN (1992). Agenda 21, Conference on Environment \& Development, Rio de Janeiro, retrieved on Nov $10^{\text {th }}, 2018$ from https://sustainabledevelopment.un.org/content/documents/Agenda21.pdf

UNESCO (2005), UN decade of education for sustainable development 2005-2014: ED/2005/PEQ/ESD/3, United Nations Educational, Scientific and Cultural Organization, Paris.

United Nations (2017), Department of Economic and Social Affairs, retrieved on $6^{\text {th }}$ March 2019, from https://www.un.org/development/desa/en/news/population/world-population-prospects-2017.html

Wallén, A., Brandt, N. and Wennersten, R. (2004), Does the Swedish consumer's choice of food influence greenhouse gas emissions? Environmental Science \& Policy, 7, 525-535. 